\title{
LABOUR LEGISLATION AND ISSUES OF IMPROVING OF LABOUR RELATIONS
}

\author{
Usmanova Muborak Akmaldjanovna \\ Military Technical Institute of National Guard of the Republic of Uzbekistan, \\ Professor of the Department of Sectoral Legal Sciences, Tashkent, Republic of Uzbekistan
}

Article DOI: https://doi.org/10.36713/epra3770

\begin{abstract}
This article analyses issues related to labour relations. In this, the author pays special attention to the regulation of the work of homeworkers, certain categories of workers, and also puts forward his proposals for improving legislation in this area.
\end{abstract}

KEY WORDS: labour relations, wage labour, work of homeworkers, domestic workers, legal regulation of labour of certain categories of workers.

\section{INTRODUCTION}

The right to work is one of the most important natural human rights. The fact that the right to work is guaranteed in practice plays a decisive role in the stability of the individual's position, not only in terms of his economic independence, but also in determining his social status in society.

The right and opportunity to work should be provided to everyone, for which the state and society should take appropriate organizational, legal, economic measures, create conditions for productive and quality work. At the same time, the state must recognize the rights of its citizens to work through its laws, create appropriate legal guarantees for their implementation and effective protection.

\section{METHODS}

Labor relations in the Republic of Uzbekistan are legally regulated in accordance with the principles of democracy, humanity and justice, and meet modern requirements in the conditions of market relations. The Labor Code of the Republic of Uzbekistan is the main normative legal document regulating labor relations, which stipulates in Article
37 of the Constitution of the Republic of Uzbekistan that "everyone has the right to work, free choice of profession, fair working conditions and unemployment protection in accordance with the law" legal norms governing all relations aimed at the implementation of the rule.

\section{RESULTS AND DISCUSSIONS}

It is known that labor legislation is adopted taking into account the interests of employees, employers and the state. This legislation is also important in that it is aimed at providing economic and social support to citizens and creating decent living conditions for them, which is one of the priorities of state policy.

Among the goals set in the Action Strategy for the five priority areas of development of the Republic of Uzbekistan for 2017-2021 are to increase employment, provide citizens with jobs and livelihoods, create the necessary conditions for them to live a prosperous and happy life using their human potential giving is a priority [1].

Due to the ongoing socio-economic reforms, market principles in labor relations have largely been resolved. Emphasis was placed on creating the 


\section{EPRA International Journal of Research and Development (IJRD)}

necessary conditions for citizens to freely choose their place of work, occupation and profession, to effectively use their physical and mental potential in the interests of themselves and their families, the state and society.

Reform of labor legislation should be associated with the effective functioning of the labor market, ensuring the harmony of individual-statesociety interests in the production process, the wellbeing of citizens, protection from unemployment, the establishment of a clear mechanism for protecting their social labor rights. The importance of the current Labor Code of the Republic of Uzbekistan as a basic sectoral law is that it provides a unified approach to the legal regulation of labor and labor relations.

We all know that in the context of deepening democratization processes in our country, the gradual transformation of all spheres of our society, including the labor sphere, is being achieved through the improvement of national legislation.

The deepening of market relations and the consequent emergence of new realities, new views in the economic life of society, the richness of content and diversity of forms of labor-related social relations have created certain problems and gaps in the regulation of labor relations. It should be noted that the market relations are constantly deepening and improving, the private sector is a significant part of production, the private sector is the leader in GDP, a large part of the economically active population is engaged in this field. The fact that different features of the workforce are supported requires new approaches to labor and labor law. Although the current Labor Code and labor legislation today cover all aspects of the labor sector, a number of its norms and rules need to be improved in line with modern requirements [2].

Based on the principle that the interests of man are of the highest value and his rights and freedoms take precedence, we consider it expedient to reflect on some new problems in labor law and their scientific solutions. Bunda:

- First, the regulation of hired labor, including international achievements that represent and regulate the rights and interests of workers, as well as the interests of entrepreneurs, the use of the experience of advanced countries, the introduction and use of effective mechanisms in them;

- secondly, in the use of hired labor, civil law and labor law criteria should be defined, a strict boundary should be drawn between such relations, and scientific and theoretical developments should be carried out;

- Thirdly, in order to achieve further expansion and strengthening of the labor legal framework, measures should be taken to ratify international instruments, in particular the conventions of the International Labor Organization, and to widely apply their methods and mechanisms;

Nowadays, many ILO Conventions have been ratified by advanced countries. In particular, 80 ILO Conventions have been ratified by the United Kingdom and 75 by Germany.

- Fourth, the work on improving our legislation should be further strengthened, making greater use of international experience in the stratified regulation of labor relations, especially in the field of legislation of independent states, which are our partners and allies in the CIS;

For example, the Labor Code of the Russian Federation introduces norms and rules that address the specifics of labor relations, which apply to different segments of employees in different sectors (education workers, transport workers, health workers, etc.). The principle of such stratification is more clearly reflected in the legislation of some other independent states.

- Fifth, it is necessary to conduct more scientific and theoretical research on issues such as the legal regulation of labor relations, the solution of new tasks and problems, the further strengthening of the rights of our citizens in the field of labor;

In the context of deepening and escalating market relations, the implementation and protection of labor rights of employees, the relationship between employees and employers, the lack of scientific research on the problems of social partnership not only worsens the situation of employees, but also affects the general legal status of the individual. It weakens the motivation to work honestly and productively. Widespread research in the field of labor law is an important factor in the development of jurisprudence, improving the legal system, thereby raising the legal awareness and culture of our citizens and the great goal of our country - building a democratic state and civil society.

\section{CONCLUSION}

In short, the development of labor legislation in the Republic of Uzbekistan corresponds to the level of socio-economic development of the country and our achievements in building the rule of law, to promote the realization of labor rights of our citizens, to prevent violations in this area, to further increase economic activity. must serve.

After all, as the President of the Republic of Uzbekistan Sh.M.Mirziyoev noted [3]: “... the consistent continuation of the noble idea that the interests of man are paramount, will be another 
great step on the path to further prosperity and wellbeing of our lives".

\section{REFERENCES}

1. Decree of the President of the Republic of Uzbekistan No. PF-4947 "On the Action Strategy for further development of the Republic of Uzbekistan".

2. National database of the legislation, 17.10.2018, No. 03/18/501/2056)

3. Mirziyoev Sh.M. "The rule of law and the protection of human interests are the key to the development of the country and the well-being of the people" // Khalk suzi. December 8, 2016. 